\title{
Klinik Örneklerde Mycobacterium Tuberculosis Saptanmasında PCR-ELISA Yönteminin Değerlendirilmesi
}

\author{
Evaluation of PCR-ELISA method for Detection of Mycobacterium tuberculosis in \\ Clinical Specimens \\ E. Müge KARAKAYALI', Nuri ÖZKÜTÜK² \\ 'Celal Bayar Üniversitesi, Tıp Fakültesi, Semt Polikliniği, Muradiye, Manisa
${ }^{2}$ Celal Bayar Üniversitesi Tıp Fakültesi, Tıbbi Mikrobiyoloji AD, Manisa
}

ÖZ

\begin{abstract}
Amaç: Tüberküloz (TB) dünyada en önemli ölüm nedenlerinden biridir. Mycobacterium tuberculosis komplex'in (MTBC) neden olduğu hastalığın erken tanısı TB'un kontrolünde önemlidir. Bu amaçla son yıllarda TB'un hızlı tanısında nükleik asit amplifikasyon test (NAAT) yöntemleri yaygın olarak kullanılmaya başlamıştır. Klinik hasta örneğinden direkt olarak MTBC saptamaya yönelik NAAT yöntemlerinden biri de "Polymerase Chain Reaction-Enzyme Immunoassay" (PCR-ELISA)'dır. Bu çalışmada, PCR-ELISA temelli ticari bir test olan ProDect MYCOBACTERIUM TUBERCULOSIS (bcs Biotect S.p.A., Cagliari, İtalya) testinin akciğer ve akciğer dışı örneklerde MTBC saptamadaki performansının araştırılması amaçlanmıştır.
\end{abstract}

Gereç ve Yöntem: Çalışmada tüberküloz kuşkulu hastalardan alınan 100 klinik örnek (76 akciğer, 24 akciğer dışı örnek) mikroskopi, kültür ve ProDect MYCOBACTERIUM TUBERCULOSIS PCR-ELISA test yöntemi ile incelenmiştir. Bu testte, amplifiye ürünün saptanması "DNA enzyme immunoassay" (DNA-ELISA) yöntemi ile mikroplaklarda gerçekleştirilir. DNA-ELISA yöntemi mikroplak kuyucuklarına kaplanmış, streptavidin-biotin bağlı, tek iplikçikli prob DNA ile amplifiye edilmiş DNA'ların hibridizasyonu esasına dayanır. Aranan DNA ile prob arasındaki bağlanma anti-DNA fare monoklonal antikor kullanılarak saptanır.

Bulgular: Altın standart yöntem olan kültür ile birlikte değerlendirildiğinde, tüm örneklerden elde edilen sonuçlara göre PCR-ELISA testinin duyarlılığı \% 68.2, özgüllüğü \% 94.1 olarak belirlenmiştir. Akciğer örneklerinde duyarlılık ve özgüllük sırası ile $\% 71.1$ ve $\% 93.5$, akciğer dışı örneklerde ise \% 61.9 ve \% 100 olarak saptanmıştır. Yayma pozitif akciğer örneklerinde ise testin duyarlıığı \% 83.3 ve özgüllüğü \% 100 olarak bulunmuştur.

Sonuç: Tüberkülozun hızlı tanısında PCR-ELISA yönteminin kısmen çok fazla ekipman gerektirmeyen bir yöntem olması nedeni ile, özellikle yayma pozitif akciğer örnekleri için, mikobakteriyoloji laboratuvarlarında tüberküloz tanısında rutin bir NAAT olarak değerlendirilebileceği sonucuna varılmıştır.

Anahtar Kelimeler: Mycobacterium tuberculosis, PCR-ELISA, tüberküloz, tanı.

\section{ABSTRACT}

Objective: Tuberculosis (TB) is one of the major causes of death worldwide. In the controlling of Tuberculosis (TB), early diagnosis of disease caused by Mycobacterium tuberculosis complex (MTBC) is vital. Hence, nucleic acid amplification tests (NAAT) for rapid diagnosis of TB came to be used widely in recent years. PCR-ELISA is a method which based on nucleic acid amplification based methods that are used for the direct detection of MTBC in clinical samples. The aim of study, was to evaluate the performance of ProDect MYCOBACTERIUM TUBERCULOSIS (bcs Biotect S.p.A., Cagliari, Italia), a commercial test based on PCR-ELISA for the detection of MTBC in pulmonary and extrapulmonary clinical samples.

Material and Methods: 100 clinical samples (76 pulmonary and 24 extrapulmonary) from patients suspected of TB were tested by microscopy, culture and ProDect MYCOBACTERIUM TUBERCULOSIS PCR-ELISA methods. In this test, detection of the amplified product is performed on microplates using DNA enzyme immunoassay. The DNA enzyme immunoassay is based on the hybridization of amplified DNA with a single-stranded DNA probe, coated on the wall of the microtitre plate wells by a streptavidin-biotin bond. The hybrid between probe and DNA being examined is detected by using an anti-DNA mouse monoclonal antibody.

Results: When PCR-ELISA test results were evaluated according to culture results which is taken as the gold standard, the sensitivity and, specificity were $68.2 \%$ and $94.1 \%$, respectively, for whole specimens. The sensitivity, specificity were $77.1 \%, 93.5 \%$ for pulmonary specimens and $61.9 \%, 100 \%$ for extrapulmonary specimens, respectively. For smear positive pulmonary specimens, the sensitivity and specificity were found to be $83.3 \%$ and $100 \%$, respectively.

Conclusion: PCR-ELISA method can be utilized cost-effectively, providing results with the use of less equipment, as a routine nucleic amplification test for the rapid diagnosis of tuberculosis in a mycobacteriology laboratory, specifically for smear positive pulmonary samples.

Keywords: Mycobacterium tuberculosis, PCR-ELISA, tuberculosis, diagnosis. 


\section{GíRiş}

Tüberküloz (TB) tüm uğraşlara rağmen, dünyada en sık ölüme neden olan enfeksiyon hastalıklarından biri olarak hala en önemli halk sağlığı problemlerinden biridir $(1,2)$.

Etkin TB kontrol programının en önemli aşaması aktif olguların erken ve doğru olarak saptanmasıdır. TB hastalarının erken tanısı ve tedavisi bu hastalıktan toplumun korunmasında en etkili yol olduğu kabul edilmektedir. Bu nedenle tüberküloza yakalandığı düşünülen hastaların tanılarını kanıtlayacak, duyarlılığı ve özgüllüğü yüksek, hızlı sonuç veren, uygulaması kolay ve pahalı olmayan laboratuvar yöntemlerinin günlük kullanıma girmesi önemli bir zorunluluktur $(3,4)$.

Son yıllarda dirençli basillerin izolasyonlardaki artış ve tanıya yönelik konvansiyonel testlerin pratik olmamaları, uzun zaman gerektirmeleri, tür düzeyinde tiplendirme de yetersiz kalmaları, rutin kullanımındaki sorunlarının çözümüne yönelik arayışları yeniden gündeme getirmiştir. Etken mikroorganizmanın nükleik asitlerinin aranmasına yönelik moleküler yöntemler tanı sürecini kısaltmada ve tedaviye yönelik antibiyotik direnci ile ilgili mutasyonların saptanmasında umut verici yöntemler olarak kullanılmaktadır $(5,6)$.

ProDect MYCOBACTERIUM TUBERCULOSIS testi (bcs Biotect S.p.A., Cagliari, İtalya) M. tuberculosis kompleks (MTBC)'in DNA'sını direkt klinik örnekten saptamaya yönelik olarak geliştirilmiş ve PCR-ELISA yöntemini kullanan ticari bir nükleik asit amplifikasyon testi (NAAT)'dir. Testte MTBC'ye spesifik IS6110 gen bölgesi, PCR yöntemi ile amplifiye edilmekte ve amplifiye edilmiş spesifik DNA bölgeleri DNA-ELISA yöntemi ile gösterilmektedir. DNA-ELISA hibridizasyon yöntemi, mikroplaktaki kuyucuklara kaplanmış, streptavidin-biotin bağlı, hedef DNA bölgesine komplementer tek iplikçikli prob DNA ile amplifiye edilmiş tek iplikçikli DNA'ların hibridizasyonu esasına dayanır. Mevcut hibrit üzerine anti-çift iplikli DNA'ya bağlanma özelliğinde olan DNA monoklonal antikor ilave edilmek- te, hibridizasyon gerçekleşmemiş ise bağlanma olmadığından yıkama ile uzaklaşmaktadır. Daha sonra ilave edilen HRP ("horseradish peroxidase") ile konjuge edilmiş Protein A, DNA ile bağlanmış antikoru tespit etmekte, kromojen-substrat ilavesi ile renklenme oluşmaktadır. Oluşan rengin spektrofotometrede okutulması ile bir absorbans değeri elde edilmekte ve bu absorbans değerinin cut-off değerinden yüksek bulunması klinik örnekte MTBC bulunduğunu göstermektedir (7).

Bu çalışmada; bir nükleik asit arama testi olan PCR-ELISA yönteminin akciğer ve akciğer dışı klinik örneklerde direkt MTBC saptanmasındaki etkinliğinin araştırılması amaçlanmıştır.

\section{GEREÇ ve YÖNTEM}

\section{Klinik Örnekler}

Çalışmaya Haziran 2006 - Eylül 2007 tarihleri arasında Celal Bayar Üniversitesi Tıp Fakültesi Hastanesi Mikobakteriyoloji laboratuvarına tüberküloz ön tanısı ile gelen 76'sı akciğer örneği, 24'ü akciğer dışı örnek olmak üzere toplam 100 klinik örnek alındı. Çalışmaya alınan akciğer örneklerinin 45'i balgam, 24'ü bronkoalveoler lavaj sıvısı, 7'si açlık mide sıvısı; akciğer dışı örneklerin ise 7'si doku örneği, 3'ü perikardiyal sıvı, 2'si beyin omurilik sıvısı (BOS), 6'sı apse, 5'i plevral sıvı ve 1'i peritoneal sıvıydı. Çalışmaya alınan klinik örnekler rastgele yöntem ile seçilmedi. Mikroskobik inceleme ve kültür sonuçlarına göre farklı gruplarda PCR-ELISA testinin etkinliğini değerlendirebilmek amacı ile klinik örnekler seçilirken, tüm grupların mümkün olduğunca istatistiksel olarak anlamlı sonuçlar vermeye yeterli olacak sayılarda olması amaçlandı.

\section{Örneklerin İşlenmesi, Mikroskobik İnceleme ve Kültür}

Tüberküloz kuşkulu hastalardan genel kurallara ve standartlara uygun şekilde alınan ve laboratuvara gönderilen klinik örneklerden normal flora elamanlarını da içerdiği kabul edilen örneklere (akciğer örnekleri gibi) standart dekontaminasyon- homojenizasyon ve yoğunlaştırma işlemi uygulanırken, normalde steril olduğu kabul edilen BOS, plevral sıvı gibi örneklere 
sadece yoğunlaştırma işlemi uygulandı. Dekontaminasyon-homojenizasyon yöntemi olarak standart NALC-NaOH yöntemi kullanıldı ve yoğunlaştırma işlemi örnekler 3000×g de 15-20 dk soğutmalı santrifüjde çevrilerek gerçekleştirildi. Dekontaminasyon-homojenizasyon ve yoğunlaştırma işleminden sonra elde edilen örnekten bir bölümü mikroskobik inceleme ve kültür için kullanıldı. Kalan yaklaşık $1 \mathrm{ml}$ 'lik örnek miktarı vida kapaklı ependorf tüplere alınarak PCR-ELISA testi için kullanılıncaya kadar -70 oC'de saklandı.

Mikroskobik inceleme için hazırlanan örnek preparatları Erlich-Ziehl-Neelsen (EZN) yöntemi ile boyanarak ARB (aside dirençli bakteri) varlığı yönünden incelendi ve sonuçlar kaydedildi.

Örneklerin kültürü için BACTEC 460TB (Becton Dickinson Diagnostic Instruments, Sparks, MD, $A B D)$ kültür sistemi ve Löwenstein-Jensen (LJ) besiyeri kullanıldı. Böylece kültür için bir sıvı besiyeri (BACTEC 12B) ve bir katı besiyeri kullanılmış oldu. Ekim sonrası LJ besiyerleri 8 hafta, BACTEC 12B şişeleri 6 hafta süre ile $37^{\circ} C^{\prime}$ 'de inkübe edildi. Kültür işlemi üretici firma önerileri ve standart prosedürlere uyularak gerçekleştirildi. Kültürde üreyen MTBC izolatlarının tanımlanmasında BACTEC NAP testi ve gerektiğinde biyokimyasal testler kullanıldı. BACTEC 12B veya $L J$ besiyerinden herhangi birinde MTBC üremesi saptandığında kültür sonucu pozitif olarak değerlendirildi.

\section{PCR-ELISA Testi}

Çalışmaya alınan klinik örneklerden DNA ekstraksiyonu, dekontamine edilmiş klinik örnekten DNA izolasyon kiti (High Pure Viral Nucleic Acid Kit, Roche Diagnostics, Mannheim, Germany) kullanılarak MTBC için kit üreticisinin önerdiği protokole uygun şekilde gerçekleştirildi. Ekstraksiyon ve öncesi tüm işlemler biyolojik güvenlik kabininde gerçekleştirildi.

MTBC nükleik asitlerinin aranmasına yönelik olarak, MTBC DNA'sının amplifikasyonu için ProDect MYCOBACTERIUM TUBERCULOSIS (BCS6860114/P) amplifikasyon kiti, amplifikasyon ürünün DNA-ELISA yöntemiyle saptanmasında ise ProDect GEN E.I.A. (BCSPDG001) (bcs Biotect S.p.A., Cagliari, İtalya) kiti kullanıldı. Tüm
PCR ve DNA-ELISA basamakları üretici firmanın önerileri doğrultusunda uygulandı.

DNA-ELISA ile elde edilen sonuçların değerlendirilmesinde, negatif kontrollerin absorbans değerleri ortalamasına 0.150 eklenerek cut-off değeri bulundu. Absorbans değeri cut-off değerinden küçük olan örnekler negatif, yüksek olan örnekler pozitif olarak değerlendirildi.

\section{İstatistiksel Analiz}

Çalışmada elde edilen Mikroskobik inceleme, kültür ve PCR-ELISA test sonuçları SPSS 11.5 (SPSS INC, Chicago, IL, USA) programına kaydedildi ve istatistiksel analizleri yapıldı. PCR-ELISA testinin, farklı gruplarda duyarlılık, özgüllük, pozitif ve negatif prediktif değerleri (PPD, NPD) kültür sonuçları altın standart kabul edilerek hesaplandı.

\section{Etik Kurul Onayı:}

Çalışmamız, 2006/0047 protokol numarası ile Celal Bayar Üniversitesi Bilimsel Araştırma Projeleri Komisyonu'nca desteklenmiş, Celal Bayar Üniversitesi Tıp Fakültesi Bilimsel Araştırmalar Etik Kurulu 10/05/2006 tarih ve 0080 sayılı yazısı ile onaylanmıştır.

\section{BULGULAR}

Çalışmada 76 (\% 76) akciğer ve 24 (\% 24) akciğer dışı olmak üzere toplam olarak 100 klinik örnek değerlendirildi. Çalışmaya alınan tüm klinik örnekler mikroskobik inceleme, kültür ve PCR-ELISA yöntemleriyle incelendi.

100 klinik örneğin ARB boyama sonrası yapılan mikroskobik incelemesinde 43 (\% 43) örnek yayma-ARB pozitif saptanırken, 57 (\% 57) örnek yayma-ARB negatif olarak değerlendirildi. Kültürde 100 örneğin 66'sında (\% 66) MTBC üremesi saptanırken, 34'ünde üreme saptanmadı. PCR-ELISA testi ile ise 47 (\% 47) örnek pozitif, 53 (\% 53) örnek negatif olarak değerlendirildi. PCR-ELISA testinin klinik örneklerde MTBC saptanmasındaki performansı, kültür sonuçları altın standart kabul edilerek değerlendirildiğinde, tüm örneklerden alınan sonuçlara göre testin duyarlılığı \% 68.2 ve , özgüllüğü \% 94.1 olarak bulundu (Tablo I). Testin PPD ve NPD'si ise sırasıyla \% 95.7 ve $\% 60.4$ olarak hesaplandı. 
Tablo I: PCR-ELISA testi sonuçlarının kültür sonuçları ile karşılaştırılması.

\begin{tabular}{|c|c|c|c|c|c|c|c|}
\hline & \multicolumn{2}{|c|}{$\begin{array}{c}\text { Pozitif MTBC } \\
\text { kültür (n) }\end{array}$} & \multicolumn{2}{|c|}{$\begin{array}{l}\text { Negatif MTBC } \\
\text { kültür (n) }\end{array}$} & \multirow[b]{2}{*}{$\begin{array}{l}\text { Toplam } \\
\text { örnek }\end{array}$} & \multirow[b]{2}{*}{ Duyarlılık } & \multirow[b]{2}{*}{ Özgüllük } \\
\hline & $\begin{array}{l}\mathrm{PE}+ \\
\text { (DP) }\end{array}$ & $\begin{array}{l}\text { PE- } \\
(\mathrm{YN})\end{array}$ & $\begin{array}{l}\mathrm{PE}+ \\
(\mathrm{YP})\end{array}$ & $\begin{array}{l}\text { PE- } \\
(\mathrm{DN})\end{array}$ & & & \\
\hline Tüm Örnekler & 45 & 21 & 2 & 32 & 100 & $\% 68.2$ & $\% 94.1$ \\
\hline $\begin{array}{l}\text { Yayma-ARB } \\
\text { pozitif örnekler }\end{array}$ & 30 & 7 & 0 & 6 & 43 & $\% 81.1$ & $\% 100.0$ \\
\hline $\begin{array}{l}\text { Yayma-ARB } \\
\text { negatif örnekler }\end{array}$ & 15 & 14 & 2 & 26 & 57 & $\% 51.7$ & $\% 92.9$ \\
\hline Akciğer örnekleri & 32 & 13 & 2 & 29 & 76 & $\% 71.1$ & $\% 93.5$ \\
\hline $\begin{array}{l}\text { Yayma-ARB } \\
\text { pozitif örnekler }\end{array}$ & 25 & 5 & 0 & 6 & 36 & $\% 83.3$ & $\% 100.0$ \\
\hline $\begin{array}{l}\text { Yayma-ARB } \\
\text { negatif örnekler }\end{array}$ & 7 & 8 & 2 & 23 & 40 & $\% 46.7$ & $\% 92.0$ \\
\hline $\begin{array}{l}\text { Akciğer diş1 } \\
\text { örnekler }\end{array}$ & 13 & 8 & 0 & 3 & 24 & $\% 61.9$ & $\% 100.0$ \\
\hline $\begin{array}{l}\text { Yayma-ARB } \\
\text { pozitif örnekler }\end{array}$ & 5 & 2 & 0 & 0 & 7 & $\% 71.1$ & - \\
\hline $\begin{array}{l}\text { Yayma-ARB } \\
\text { negatif örnekler }\end{array}$ & 8 & 6 & 0 & 3 & 17 & $\% 57.1$ & $\% 100.0$ \\
\hline
\end{tabular}

Akciğer örneklerinin \% 59.2'sinde (45/76) kültür pozitif saptanırken, \% 44.7'sinde (34/76) PCR-ELISA testi pozitif saptandı. Kültür pozitif 13 (\% 17.1) akciğer örneği PCR-ELISA testi ile negatif bulunurken, 2 (\% 26.3) kültür negatif akciğer örneği PCR-ELISA testi ile pozitif bulundu. Bu sonuçlara göre akciğer örneklerinde PCR-ELISA testinin duyarlılığı \% 71.1 ve özgüllüğü \% 93.5 hesaplandı. Akciğer örneklerinden yayma-ARB pozitif saptanan 36 (\% 47.4) örneğin \% 83.3'ü (30/36) kültür pozitif saptanırken, \% 69.4'ü (25/36) PCR-ELISA testi ile pozitif olduğu görüldü. Bu yayma-ARB pozitif akciğer örneklerinden 5'i (\% 13.9) kültürde pozitif fakat PCR-ELISA testinde negatif bulundu. Mikroskobik incelemesi yayma-ARB pozitif akciğer örneklerinde PCR-ELISA testinin duyarlılığının \% 83.3 ve özgüllüğünün \% 100.0 olduğu saptandı. Yayma-ARB negatif 40 akciğer örneğinden alınan sonuçlara göre ise bu grupta PCR-ELISA testinin duyarlılığı ve özgüllüğü sırasıyla \% 46.7 ve \% 92.0 bulundu (Tablo I).

Akciğer dışı 24 örneğin \% 87.5'inde (21/24) kültür pozitif saptanırken, \% 54.2'sinde (13/24) PCR-ELISA testi pozitif saptandı. 8 kültür pozitif akciğer dışı örnek PCR-ELISA testi ile negatif bulundu. Akciğer dışı örneklerde PCR-ELISA testinin duyarlılığı \% 61.9 ve özgüllüğü \% 100 olarak hesaplandı (Tablo I).

\section{TARTIŞMA}

Tanı, tedavi ve kontrol yöntemlerindeki gelişmelere rağmen, tüberküloz önemli bir halk sağIığı sorunu olmaya devam etmektedir. MTBC'nin hızlı ve doğru laboratuvar tanısı TB'lu hastaların tedavisinde ve hastalığın kontrolünde çok önemlidir $(1,2)$. MTBC'nin laboratuvar tanısında yıllardan beri kullanılmakta olan mikroskopi ve kültür, düşük duyarlılık ve geç sonuç verme gibi sınırlamalara sahiptir. Tanıda yaşanan bu sorunların aşılabilmesi için son yıllarda direkt klinik örneklerdeki MTBC'nin DNA'sını çoğaltmaya yönelik olarak düzenlenmiş NAAT'leri geliştirilmiştir ve TB tanısında rutin kullanımda yer almaya başlamışlardır (4-6, 8- 12).

Direkt klinik örnekten MTBC'nin DNA'sını saptamaya yönelik bir NAAT olan PCR-ELISA testinde MTBC'ye spesifik IS6110 gen bölgesi PCR yöntemi ile amplifiye edilmekte ve amplifiye edilmiş spesifik DNA bölgeleri DNA-ELISA yöntemi ile 
gösterilmektedir. Yam WC. ve arkadaşları akciğer ve akciğer dışı örneklerde bu yöntemin duyarlılık ve özgüllüğünü sırasıyla \% 97 ve \% 100 olarak saptamışlardır (13). PCR-ELISA testinin bir ticari kiti geliştirilmiş, ancak literatürde bu test kitinin değerlendirildiği yeterli sayıda çalışma olmadığı görülmüştür (7). Bu çalışmada direkt klinik örneklerden MTBC'nin saptanmasında ProDect MYCOBACTERIUM TUBERCULOSIS testinin performansı değerlendirilmiştir.

Çalışmada yalancı pozitiflik oranının oldukça düşük olduğu görülmüş, toplam 100 klinik örneğin sadece 2'sinde kültür negatif, PCR-ELISA testi pozitif saptanmıştır (özgüllük $=\%$ 94.1). Nükleik asit amplifikasyon testlerinde yalancı pozitiflik nedenleri arasında test süresince çapraz kontaminasyon ve hastanın tüberküloz tedavisi altında olması sayılabilmektedir (14, 15 ). Bu nedenledir ki CDC (ABD Hastalık Kontrol ve Korunma Merkezleri) yedi günden fazla süredir TB tedavisi gören hastalarda alınan klinik örneklerde NAAT çalışılmamasını önermektedir (14). Bu çalışmadaki yalancı pozitif iki örneğin yayma-ARB negatif solunum örneği (balgam) olduğu görülmüş, fakat hastanın klinik ve diğer bulgularla TB tanısı alıp almadığı veya örneği verdiği dönemde ilaç alıp almadığı bilgisine ulaşılamamıştır. Ayrıca yanlış pozitifliğin bir diğer nedeni de altın standart olarak sadece kültür pozitifliğinin kabul edilmesi olabilmektedir. Mikroskobik incelemede yayma-ARB negatif olup az miktarda basil çıkarılan durumlarda basilin örnek içinde dengesiz dağılımına bağlı olarak kültürde üreme olmadığı halde ticari direkt NAAT'leri pozitif olarak saptanabilmektedir (15). Çalışmada toplam 100 klinik örneğin (76 akciğer ve 24 akciğer dışı) 21'inde kültür pozitifPCR-ELISA testi negatif saptanmıştır (duyarlılık $=\%$ 68.2). TB tanısında kullanılan ticari direkt NAAT'lerinde çok değişik duyarlılık oranları bildirilmekte ve bu testlerde duyarlılığın istenilen düzeye getirilememesi bu testlerin eksikliği olarak görülmektedir. En başta gelen yalancı negatiflik nedenleri örnekte amplifikasyon inhibitörü maddelerin bulunması ve örnekteki çok az sayıda basilin (yayma-ARB negatif örnekler) örnek içinde homojen dağılmamış olmasıdır (1416). Bu çalışmada yalancı negatif sonuç veren 21 örneğin 14'ünün yayma-ARB negatif, 3 'ünün ise sadece yayma-ARB düşük düzey pozitif $(1+)$ olduğu görülmüştür. Yalancı negatifliğe neden olan faktörler örnek türüne göre değişmektedir. Bu nedenle NAAT'lerinin performansı örneğin türüne (akciğer ve akciğer dışı) ve mikroskobik inceleme sonucuna göre (yayma-ARB pozitif ve negatif) ayrı gruplarda değerlendirilmektedir.

Çalışmamızda, 76 akciğer örneğinden alınan sonuçlar değerlendirildiğinde PCR-ELISA testinin duyarlılığı \% 71.1 ve özgüllüğü \% 93.5 bulunmuştur. Akciğer örneklerinden alınan sonuçlar mikroskobik inceleme sonuçlarına göre değerlendirildiğinde, PCR-ELISA testinin duyarlılığı ve özgüllüğü sırasıyla; yayma-ARB negatif akciğer örneklerinde \% 46.7 ve \% 92.0; yayma-ARB pozitif akciğer örneklerinde \% 83.3 ve özgüllüğü \% 100.0 bulunmuştur. TB tanısında kullanılan diğer direkt NAAT'lerinde de akciğer örneklerinde, özellikle de yayma-ARB pozitif akciğer örneklerinde duyarlılık yüksek bildirilmiştir. $\mathrm{Bu}$ nedenle ticari NAAT'leri genellikle yayma-ARB pozitif akciğer örneklerinde tanı amacıyla kullanım için standardize edilmiştir (14). Bizim çaIışmamızda da PCR-ELISA testinin duyarlıığı ve özgüllüğü diğer ticari NAAT'leri için bildirilen değerlere benzer bulunmuştur.

Piersimoni ve ark. TB tanısında kullanılan ticari direkt NAAT'lerinin değerlendirildiği çalışmaIarın sonuçlarını analiz etmişler ve akciğer dışı örneklerde bu testler için \% 91.3-100 arasında özgüllük ve \% 27.3-82.3 arasında duyarlılık sonuçları bildirildiğini saptamışlardır. Yine aynı analizde yayma-ARB negatif akciğer dışı örneklerde \% 17.2'lere kadar düşen duyarlılık sonuçları bildirildiğini görmüşlerdir (14). Çalışmamızda akciğer dışı örneklerde PCR-ELISA testinin duyarlılığı \% 61.9 ve özgüllüğü \% 100 bulunmuştur. Akciğer dışı örneklerde duyarlılığın düşük olmasının en önemli nedeni bu tür örneklerde inhibitör maddelerin daha yüksek oranda bulunması ve bu tür örneklerde basil sayısının daha az sayıda bulunmasıdır (16). Çalışmamızda da test edilen 24 akciğer dışı örneğin 17'si yayma-ARB negatifti. Kültür pozitif PCR-ELISA negatif olan akciğer dışı 8 örneğin, 6'sı yayma-ARB negatif olan örneklerdi, diğer ikisi ise düşük düzeyde yayma-ARB pozitif pozitifliğine (1+) sahipti. Mikroskobik incelemede daha yüksek düzeyde yayma-ARB pozitifliğine $(>1+)$ sahip tüm kültür pozitif akciğer dışı örnekler PCR-ELISA testi ile pozitif olarak saptanabilmiştir. Bazı ticari direkt NAAT'lerinde bulunan internal amplifikasyon kontrolü (IAC), örnekteki 
amplifikasyon inhibitörü maddelerin varlığını gösterebilmektedir. PCR-ELISA testinde IAC bulunmamaktadır (14).

Direkt NAAT'lerinin en büyük avantajı hızlı tanıdır. Bu testler ile bir gün içinde (2.5-12 saat) sonuç verilebilmektedir (14). Bu çalışmada değerlendirilen ProDect MYCOBACTERIUM TUBERCULOSIS testi de 6-7 saatte tamamlanmaktadır. Ticari direkt NAAT'lerinin en önemli dezavantajlarından biri ise maliyetlerinin yüksek olması nedeniyle özellikle gelişmekte olan ülkelerde rutin tanı testi olarak kullanılmalarının kısıtlı olmasıdır. ProDect MYCOBACTERIUM TUBERCULOSIS testinin amplifikasyon basamağı PCR temellidir ve diğer ticari NAAT'lerinin amplifikasyon basamağına benzer maliyete sahiptir. Fakat saptama basamağı DNA-ELISA tekniği ile gerçekleşmektedir ve pahalı cihaz ve ekipman gerektirmemektedir.

Sonuç olarak, tüberkülozun hızlı tanısında PCR-ELISA testinin (ProDect MYCOBACTERIUM TUBERCULOSIS) kısmen çok fazla ekipman gerektirmeyen bir yöntem olması nedeni ile, özellikle yayma pozitif akciğer örnekleri için, mikobakteriyoloji laboratuvarlarında tüberküloz tanısında rutin nükleik asit amplifikasyon testi olarak değerlendirilebileceği sonucuna varılmıştır. PCR-ELISA testinin yüksek özgüllüğü sayesinde, bu testle elde edilen pozitif sonuçların tanıyı doğrulmada yararlı olacağı, fakat negatif sonuçların klinik bulgularla beraber değerlendirilmesinin ve kültür sonuçları alındığında kültür sonuçları ile tanının doğrulanmasının uygun olacağı düşünülmüştür.

\section{KAYNAKLAR}

1. WHO. Global tuberculosis report 2013. World Health Organization, Geneva, Switzerland, 2013.

2. Global tuberculosis control: surveillance, planning, financing. WHO report 2007. Geneva, World Health Organization WHO/ $\mathrm{HTM} / \mathrm{TB} / 2007.376$.

3. Centers for Disease Control and Prevention (CDC). Controlling Tuberculosis in the United States (Recommendations from the American Thoracic Society, CDC, and the Infectious Diseases Society of America). MMWR Morb Mortal Wkly Rep 2005;54:RR12.

4. Pai M, Palamountain KM. New tuberculosis technologies: challenges for retooling and scale-up. Int J Tuberc Lung Dis 2012; 16(10):1281-90.
5. Wilson ML. Recent advances in the laboratory detection of Mycobacterium tuberculosis complex and drug resistance. Clin Infect Dis 2011; 52 (11): 1350-5.

6. Pai M, Minion J, Steingart K, Ramsay A. New and improved tuberculosis diagnostics: evidence, policy, practice, and impact. Curr Opin Pulm Med 2010; 16: 271-84

7. ProDect MYCOBACTERIUM TUBERCULOSIS. Product and procedure manual. bcs Biotect S.p.A., Cagliari, Italia, 2004.

8. Guillerm M, Usdin M, Arkinstall J. Tuberculosis Diagnosis and drug sensitivity Testing; An overview of the current diagnostic pipeline. Campaign for Access to Essential Medicines, Geneva, Switzerland, 2006: 21-8.

9. WHO. Policy statement: automated real-time nucleic acid amplification technology for rapid and simultaneous detection of tuberculosis and rifampicin resistance: Xpert MTB/RIF system. World Health Organization, Geneva, Switzerland, 2011.

10. Centers for Disease Control and Prevention (CDC). Updated guidelines for the use of nucleic acid amplification tests in the diagnosis of tuberculosis. MMWR Morb Mortal Wkly Rep. 2009;58(1):7-10.

11. O'Grady J, Maeurer M, Mwaba P, et. al. New and improved diagnostics for detection of drug-resistant pulmonary tuberculosis. Current Opinion in Pulmonary Medicine 2011,17:134-41.

12. Nagdev KJ, Kashyap RS, Deshpande PS, Purohit HJ, Taori GM, Daginawala HF. Comparative evaluation of a PCR assay with an in-house ELISA method for diagnosis of Tuberculous meningitis. Med Sci Monit. 2010;16(6):289-95.

13. Yam WC, Cheng VCC, Hui WT, et. al. Direct detection of Mycobacterium tuberculosis in clinical specimens using singletube biotinylated nested polymerase chain reaction-enzyme linked immunoassay (PCR-ELISA). Diagnostic Microbiology and Infectious Disease 2004;48:271-5.

14. Piersimoni C, Scarparo C. Relevence of Commercial Amplification Methods for Direct Detection of Mycobacterium tuberculosis complex in Clinical Samples. J Clin Microbiol 2003;41:5355-65.

15. Çavuşoğlu C. Moleküler tanı yöntemlerinde yaşanan sorunlar. IV. Tüberküloz Sempozyumu, Sempozyum kitabı, Malatya, 2005: 81-7.

16. Huggett JF, McHugh TD, Zumla A. Tuberculosis: amplification-based clinical diagnostic techniques. Int Biochem Cell Biology 2003;35:1407-12. 